\title{
INDONESIAN WARSHIP HISTORY INFORMATION SYSTEM OF INDONESIAN FLEET BASED ON WEB
}

\author{
Zainal Syahlan, Khairul Huda, M. Syaifi, Edy Widodo \\ D-3 Informatics Engineering, Indonesian Naval Technology College \\ www.sttal.ac.id
}

\begin{abstract}
The development of information technology also developed in line with the development of human civilization. The development of information technology is very helpful, one of which is the internet. The use of the internet has developed into an appropriate means to convey information that is fast, effective and accurate. Submission of information is not limited to all soldiers and the general public by utilizing technological facilities, namely websites. In conveying the history of Indonesia Warship Raden Eddy Martadinata 331 and Indonesia Warship I Gusti Ngurah Rai 332 are still stored in the form of documents on a computer and are still printed in the form of sheets of paper. In conveying the history of Indonesia Warship, it must be developed further to convey information in the current era. Historical research that executive focuses on the past. So far, information on the Indonesia Warship Indonesia Warship's historical information system Raden Eddy Martadinata - 331 and Indonesia Warship I Gusti Ngurah Rai - 332 on the web-based Indonesian Armed Forces fleet are still in print. besides using information books, then try to make other alternatives by creating a website, besides that members are expected to access information easily and efficiently. With the ineffectiveness in managing Indonesia Warship Indonesia Warship historical data Raden Eddy Martadinata - 331 and Indonesia Warship I Gusti Ngurah Rai - 332, a design of the Indonesia Warship historical information system was built in the web-based Indonesian Armada fleet which aims to facilitate the process of Indonesia Warship history search. $P H P$ as a programmer and MySQL as the database.
\end{abstract}

Keywords: Website-Based Indonesia Warship History Information System. PHP MySQL.

\section{INTRODUCTION}

\section{$1.1 \quad$ Background}

Indonesia is a maritime country that has a large sea area. That is why to protect Indonesia's territorial waters, a strong marine fleet is needed. One of the maritime fleets that is a mainstay of Indonesia is the Indonesia Warship.

The extent of the sea in the territorial waters of the Republic of Indonesia which is part of the Indonesian patrol area is a demanding task that is not easy for the Indonesian Navy. One of the most important tasks in preventing violations of maritime law, illegal fishing and fishing is conducting maritime patrols in vulnerable waters. In carrying out patrol duties and checking maritime transportation facilities, important things to consider are the readiness of the patrol boat to be used.

Historical research is reviewers and other sources that contain information about the past and are carried out systematically. Or in other words, the research that is assigned reflects the symptoms, but not what happened at the time the study was conducted.

Historical research that executive focuses on the past. This research tries to reconstruct what happened in the past as completely and accurately as possible, and usually explains why it happened. In finding data carried out systematically in order to be able to describe, explain, and understand the activities or event that happened some time ago. 
All this time, information on the Indonesia Warship historical information system on the Indonesian-based Armada RI is still on the web delivered in printed form. Members can easily find out information about the Indonesia Warship historical information system in the Indonesian Armed Forces fleet webbased in addition to using books, then try to make other alternatives by creating a website, in addition members are expected to access information easily and efficiently

With ineffectiveness in managing Indonesia Warship historical data, a design of the Indonesia Warship historical information system was built on the web-based Armada RI that aims to facilitate the process of searching for Indonesia Warship history.

\section{LITERATURE REVIEW}

\subsection{Theoretical Basis}

Website or site is a collection of pages that display text, still or moving images, animated data, sound, video or a combination of all, both static and dynamic that form a series of interrelated buildings where each is connected with networks page. Domain is considered to be closely related to the understanding of the area of authority. An organizational unit with administrative responsibilities to appoint a network at home. Unique name to guarantee the address on the internet page. This domain consists of two or more parts separated by dots. For example email.yahoo.com, and www.hotmail.com. Hosting comes from the word host. The computer is connected to a network. Utilizing the facilities available in a computer connected to the network. Internet services for placing information both for web pages, email storage, databases, etc. To put it simply, this service is a solution to place your web pages must always be online. Thus, we do not need to provide a special computer that is always online at the office or at home, but enough to work with this hosting provider. To support the making of this thesis, it is necessary to state things or theories relating to the problem and scope of the discussion as a basis.

\subsubsection{Panorama Image.}

Panoramic images use special methods needed to form images with wide viewing angles and small disturbances. This common image has overlapping parts and this process will create a smooth connection between each normal image pair. Another common method is to work based on geometric transformations in all parts of public imagery. In this method, there are images and reference images that will be combined. The merged images are changed so that the objects in this method will produce a greater deviation for the aggregation of a larger viewpoint to combine a larger view so that it cannot be used for creating 360 'panoramic images.

\subsubsection{Pt Gui Panorama}

PTGui is a program for
designing panoramic images for Windows and Mac OS $X$ developed by New House Internet Services BV. PT Gui has been created as a graphical user interface for the Helmut Dersch panoramic tool. It has a special sewing and mixing machine and compatibility with panoramic tools.

\subsubsection{Internet}

Etymologically, the internet comes from English, which means a network that is meaningful and clean, so that relationships can be interpreted between networks. Literally, the internet (short for connected circuits) of circuits is connected to computers in several series. When the Internet ("big") is a public computer system, globally, it uses the TCP / IP protocol as a packetswitching protocol. The biggest Internet series on the Internet. How to connect the circuit with this method is called internet working.

\subsubsection{Website}

Website is often also called the web, it can be interpreted as a collection of pages that display various kinds of information text, data, images, still or 
moving, animated data, sound, video or a combination of them, both those that are stigmatized interrelated where each - connected to a network of pages or hyperlinks.

\section{$2.15 S Q L$}

Microsoft SQL Server is a Microsoft database management system (RDBMS). The main question is Transact-SQL, the standard implementation of the ANSI / ISO SQL standard used by Microsoft and Sybase. SQL Server is generally used in the business world with small and medium databases, but later developed with SQL Server in a database.

\subsubsection{PHP (Hypertext Processor)}

Prihatna (2005), PHP is a scripting language that is printed on a server and processed in the process. Created by Formulas originally by making a personal project and improved by six developers and reborn with the name PHP. Specifically, PHP is designed to create dynamic websites, which means that PHP can form the desired appearance. PHP has a good ability in mathematical calculations, in terms of email network information and regular disclosures. In addition, PHP supports several database servers such as MySQL, ORACLE, Sysbase, and SQL Server.

\subsubsection{Bootsrap}

Zaenal A. Rozi (2005), bootsrap is a ready-made application for the front of the site. Bootsrap is also one of the most popular HTML, CSS, and javascript templates among web developers that is used to develop responsive web pages. Web pages can be set according to the size of the monitor device used by users when accessing the site from a browser. Initially, bootsrap was called "Blueprint Twiter" which was developed by Mark Otto and Jacob Thornto as a framework for promoting internal consistency.

\subsubsection{Domain}

Domain is a unique name that is assigned to identify the IP address of a computer server such as a web server or internet email server. Domains make it easy for internet users to access their servers and make it easier for them to remember the servers they visit.

\subsubsection{Hosting}

Hosting (Web Hosting / Hosting) is a place to store the dates required by the website and accessed through the Internet. Data can be in the form of files, images, emails, applications / programs / scripts and databases. Hosting Insights can be linked to the following examples: This site is respected with stalls / rooms from the Mall.

\section{RESEARCH METHODS}

\subsection{Research Procedure}

The research procedure is an explanation of the research process to be carried out, starting from the design work system diagram to the expected system input and output. The overall research process can be seen in Figure 1. Following is a Flowchart of the overall research procedure.

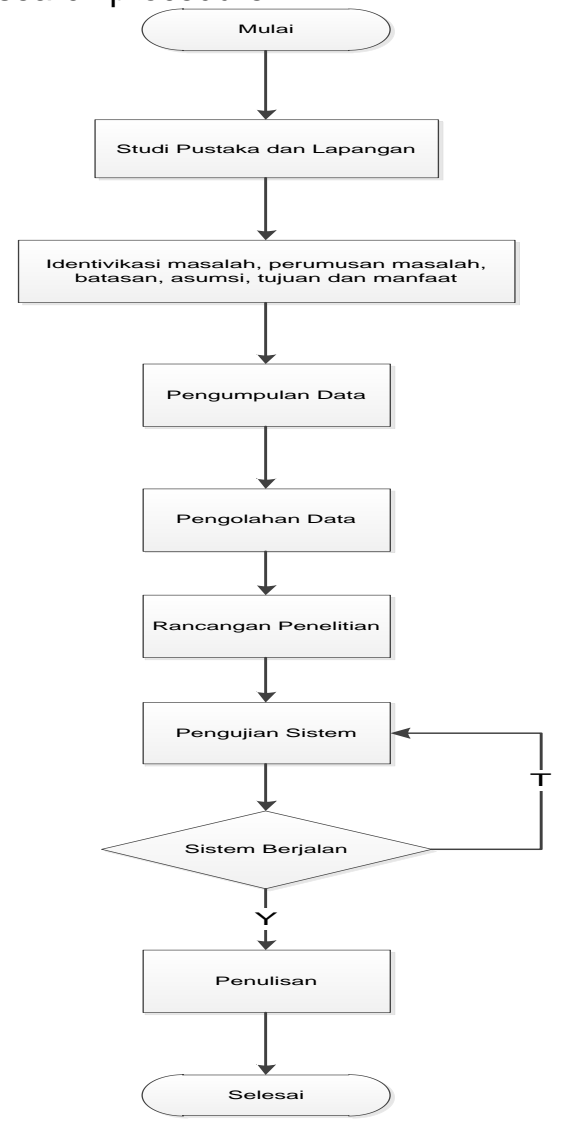

Figure 1 Workflow System Flow Diagram 


\subsubsection{Tools and Materials}

Research that has been carried out In this study several tools and materials are needed to simplify the design and research tests. The tools and materials used for research are:

a. Personal Computer (PC) / Laptop is used during testing.

b. The Mysql Database Software is used as a database management system processor.

c. PHP is a server-side scripting language that can be integrated with HTML to create dynamic WEB pages.

d. Domain. is a unique name used to recognize an address (IP address) from a computer server, such as a web server or e-mail server on the Internet.

e. Hosting is a rental place for data needed by a website and an therefore be accessed via the internet.

f. Boostrap is a framework because of the good performance the application package is ready to use to create a front-end website. Bootsrap is also one of the most popular HTML, CSS, and javascript templates among web developers used to develop responsive websites. So that web pages can later adjust according to the size of the monitor device the user is using when accessing the website from a browser.

g. USB drivers are files that allow hardware to communicate with the computer's operating system. This USB device contains a variety of electronic items, including but limited: keyboards, monitors, cameras, flash drives, mice, speakers, MP3 players, smartphones, printers and external hard drives. Drivers are an important part because the device does not function properly if it is not installed correctly.

h. Universal Serial Bus (USB) is a serial bus stand to connect devices, usually on computers, but is also used in other devices, such as game consoles, cellphones, and PDAs. The USB system has an asymmetrical design, which is a variety of host controllers and some equipment is connected "tree shaped" using a special hub device.

i. Notes ++ is a text editor that runs on the Windows Operating System (OS). Notepad ++ uses the Scintilla component here to display and edit text and source code files from different programming languages. Notepad ++ is distributed as a free software (free) This project is offered by Sourceforge.net with more than 27 million downloads and twice the SourceForge Community Choice Award for best developer tools.

\subsubsection{Research Design}

Research Design on Information System construction design Indonesia Warship history in the ranks of the Republic of Indonesia web-based Fleet includes:

a. Research Overview Plans. The general design description of the research is the stage of studying the current system based on the results of a survey of existing problems. Then various survey data are processed to get a general picture of the results obtained.

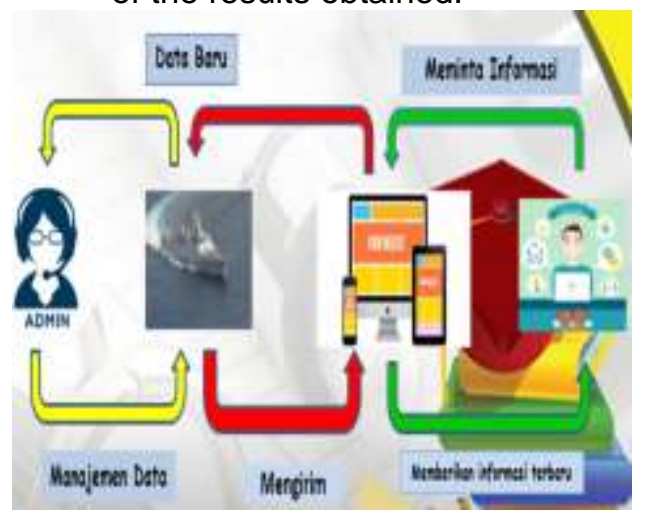

Figure 2: Overview of Research Making Website 
From the information on the general image of the website development research can be explained as the ship data management admin displays the results of the data to the website, then the website provides an information to the website visitors. Visitors ask for information to the website then the website is given information on vessel data that has been processed by the admin.

b. The draft Analysis System Document Flow about the Historical Information System Indonesia Warship in the ranks of the Republic of Indonesia-based Fleet includes.

c. Document Flow Diagram is a document from a chart that shows the flow / flow of documents from one part to another in the system logically by describing the design of each part of the organization involved in processing documents in the process carried out by the system. The flow of documents in this system can be seen in Figure 3 below:

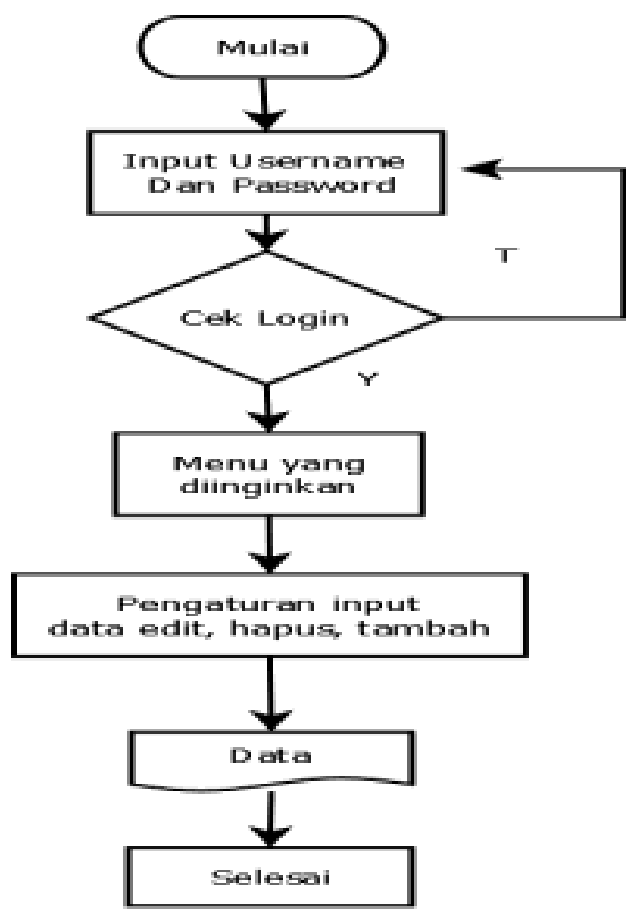

Figure 3 Indonesia Warship History Information System Document Flow a. Indonesia Warship Historical Information Flow Diagram

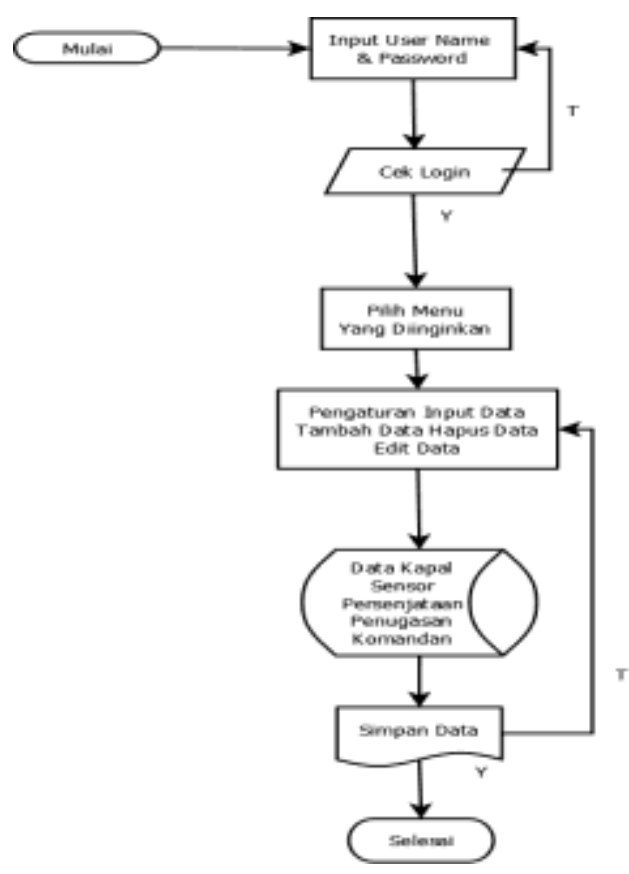

Figure 4 Indonesia Warship Historical Information Flow Diagram

e. Relation of Indonesia
Warship History Information
System Database

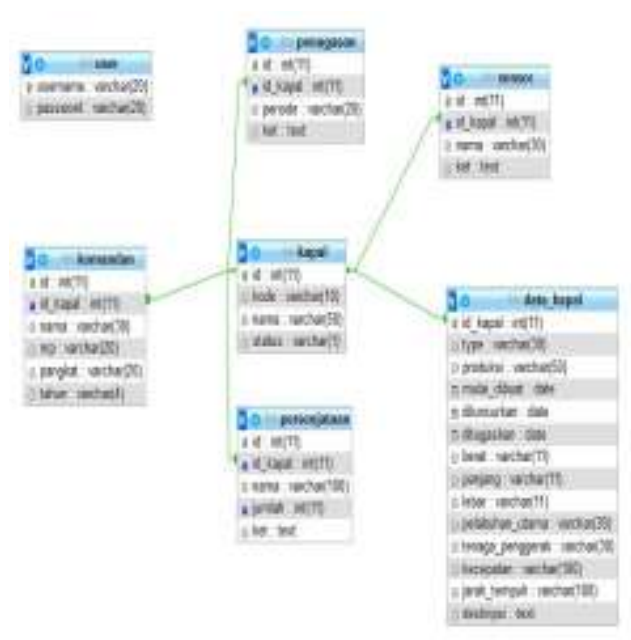

Figure 5 Relation of Indonesia Warship History Information System Database

\subsubsection{Pengumpulan Data}

Data collection method is a method used to find out what and how the required data can be collected, so that the final investigation can provide valid information and can be used. Data collection methods that will be used in this final project are the method of 
observation, interview and literature study:

a. Observation method is a method of collecting data, which is done by direct observation of data related to this research.

b. Interview method is a method to collect data that are executed as questions and directly answered to the speaker related to the data needed in this study. The application method is carried out directly with Indonesia Warship staff.

c. The author also conducts literature research by finding references by collecting documents or archives, books, magazines and internet media related to the history of Indonesia Warship.

\section{ANALYSIS AND DISCUSSION}

\subsection{Analysis of Data and Research} Results.

activities to study, classify, systematically, interpret and validate data so that the phenomenon has social, academic and scientific value. Activities in data analysis are grouping data based on variables and types of respondents, compiling data based on variables and all respondents, sending data for each variable being reviewed, doing calculations to answer the problem formulation and doing calculations to test hypotheses, the final step is not ready. Research results are studies of the validity of research results.

Discussion of research findings can be referred to as the original thought of researchers to provide explanations and interpretations of research results that have been analyzed to answer research questions. Basically, the discussion of research results is a discussion of the results obtained.

\subsubsection{Design}

Design is a process carried out on a project that we are working on, starting from the research design, to the finished results that will be functioned. In principle, good design and systematic can provide convenience in the manufacturing process to become an application system that really functions as it should. In designing the Indonesia Warship's historical information system, it consists of several designs, namely input / output design, and form design.

\section{a. Input / Output Design}

Input / output design is a design of the Indonesia Warship historical information system in the web-based $\mathrm{Ri}$ fleet, as a whole consisting of input and output designs. The explanation and appearance of each design will be discussed in the explanation of each design.

b. Input Design

Input design is a system application design that functions as an input in the Indonesia Warship historical information system in the web-based Ri fleet. The overall input design consists of a login form in accordance with access rights, a home form for the admin.

\section{c. Interfaces}

The interface is a form of graphical display that is directly related to the user. The user interface functions to connect between the user and the operating system, so that the computer can be used. Interface design is the overall design of the information system built.

\section{d. Domain}

Domain is a unique name given to identify the address (IP address) of a computer server such as a web server or e-mail server on the internet. Domain makes it easy for internet users to access the server and makes it easier to remember the server visited rather than having to remember a series of IP Address numbers. for more clarity, can be seen in Figure 6. 


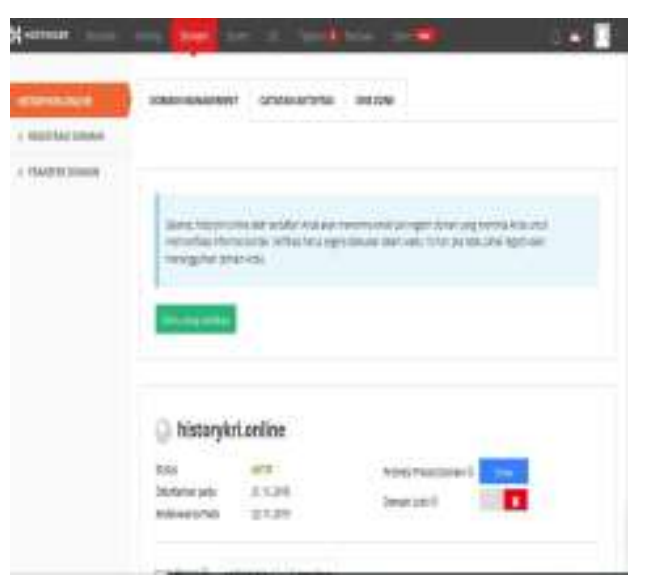

Figure 6 Domain

e. Hosting adalah space harddisk dalam komputer server yang digunakan untuk penyimpanan database, email dan file web.

f. There are many hosting specifications, but a few important ones re:

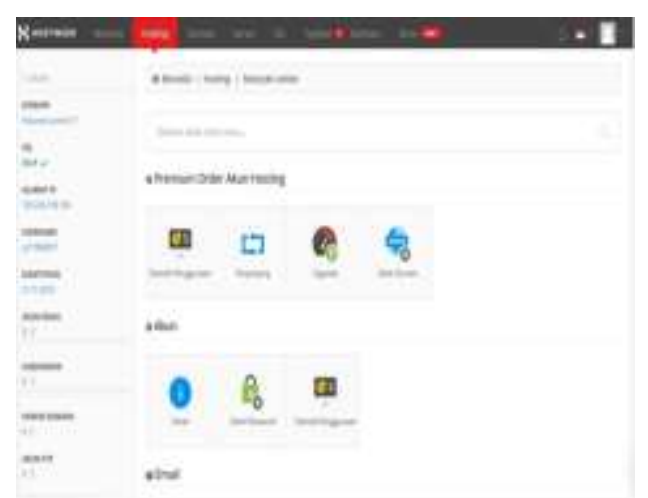

Figure 7 Hosting

g. Dashboard Design.

Dashboard starting page on the information system that was built, designed can be seen by all visitors without having to $\log$ in first. At the right of access that can be logged only certain people who have a username and password that has been adjusted to the needs of the organization. The dashboard design of the home page can be seen in Figure 8.
1) Start Page Dashboard
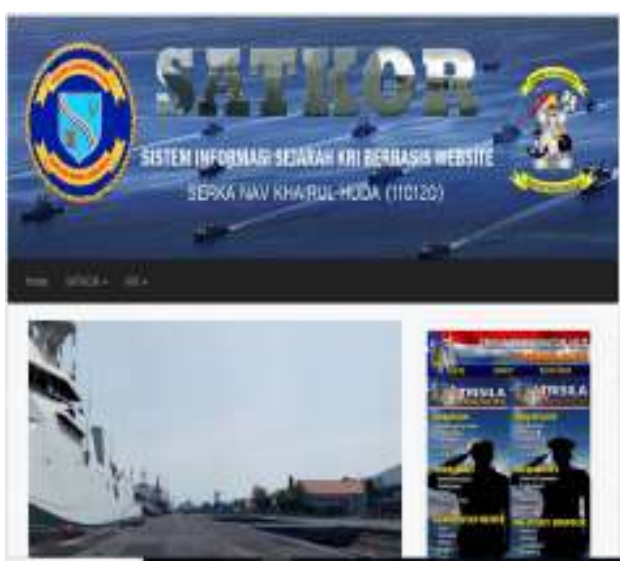

Figure 8 Dashboard Initial View

On the Dashboard the initial display of the information system displays the history of Indonesia Warship so that the Dashboard display of the initial page on this information system makes it easy for visitors to this website to understand the history of the Indonesia Warship that has been built and designed so that it can be seen without having to log in first.

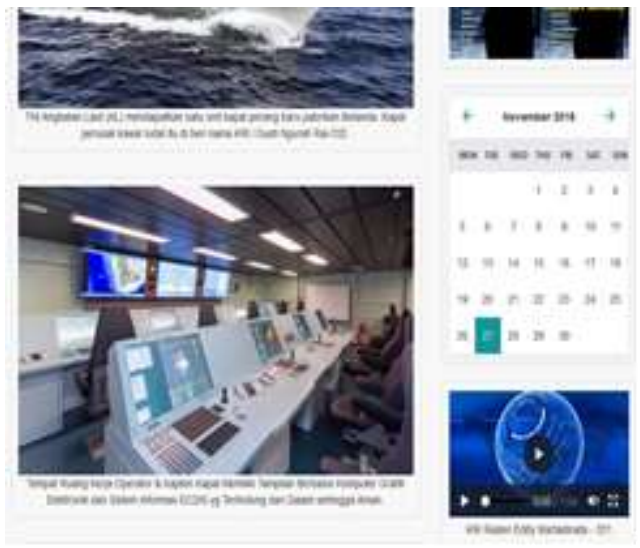

Figure 9 Dashboard Initial View

On the dashboard view of this page, you can see the Operators \& Captain's Office Workspace. It has a Computer-Based Display of Electronic Graphics and ECDIS Information Systems that are Protected from the Inside so that it is Safe. 


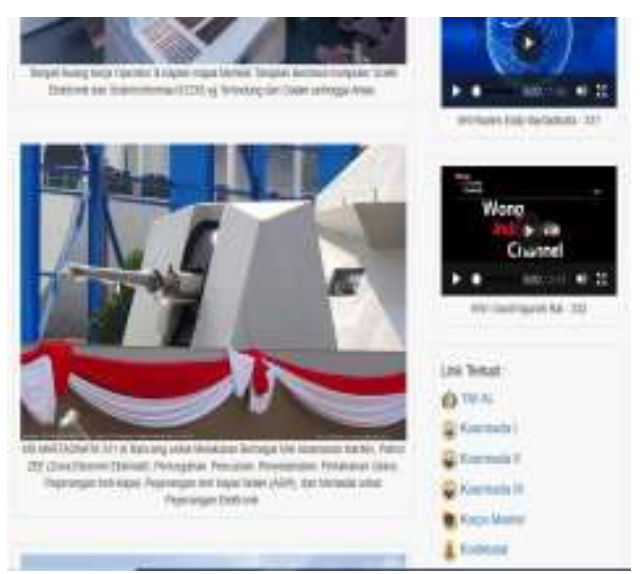

Figure 10 Dashboard Initial View

In this Dasbord view, Indonesia Warship Martadinata 331 is designed to carry out various maritime security missions, ZEE patrols (exclusive economic zones), prevention, search, rescue, air defense, anti-ship warfare, anti-submarine warfare (ASW), and adequate for electronic warfare.
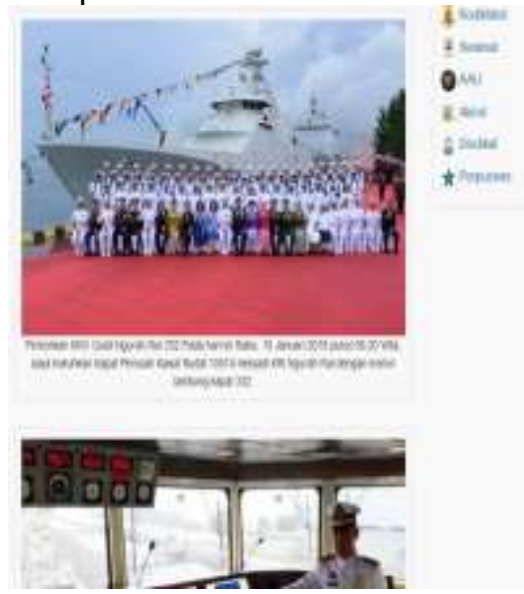

Figure 11 Dashboard Initial Display of the Inauguration of the Indonesia Warship

In Dashboard this view can be seen in the Indonesia Warship Platform Room of the ship's command room where the steering wheel of the ship is placed, navigation equipment to determine the position of the ship is located and there is usually a commander's room and a radio room next to the bridge. The bridge is usually placed in a position that has good visibility in all directions.

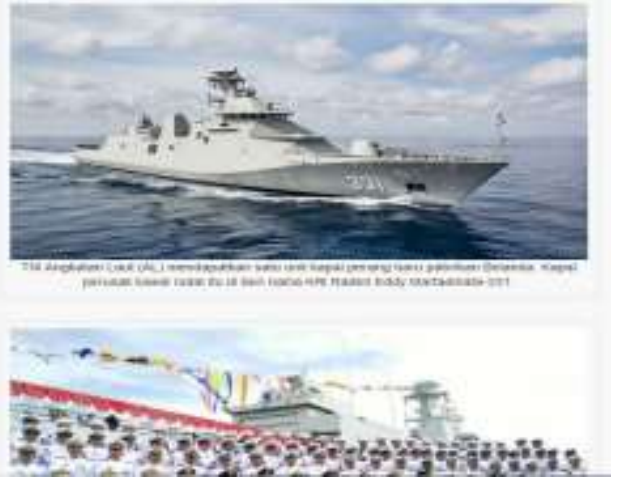

Figure 12 Dashboard Initial View

On the initial dashbord display, this is an illustration of the inauguration of the Inauguration of the Indonesia Warship I Gusti Ngurah Rai 332.

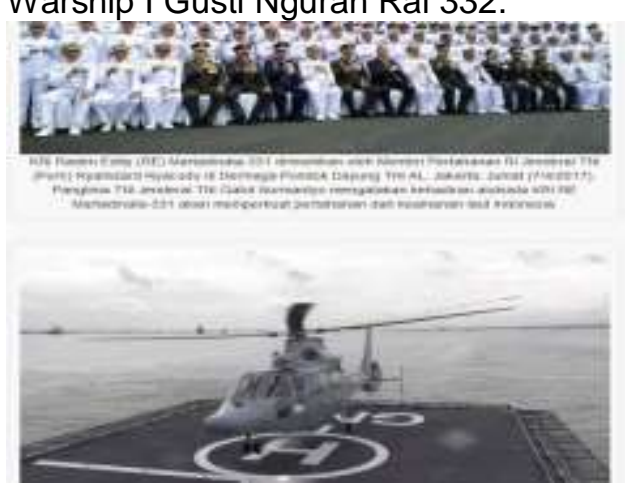

Figure 13 Dashboard Initial View

On this dashboard displays the helly container contained in the picture RI Raden Eddy (RE) Martadinata-331 inaugurated by the Minister of Defense of the Republic of Indonesia (TNI) General Ryamizard Ryacudu at the Pondok Padung Navy Pier

2) Login Form Design.

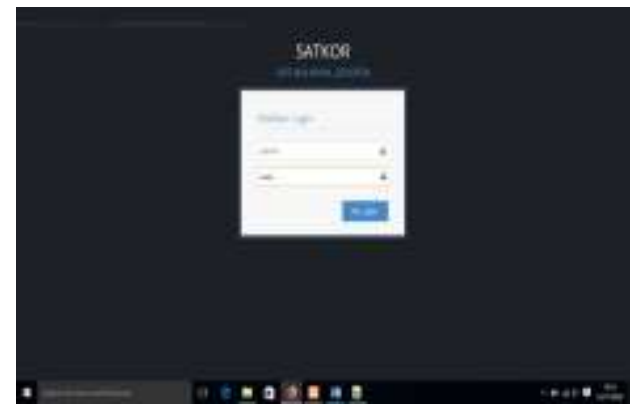

Figure 14 Login Form Design 
Login form design is a form that is intended for admins who have access to enter the system. Not everyone can log in, because only certain parties have access in the form of a username and password. can be seen in Figure 14.

\section{a. Software}

Software is an intangible computer system, because it cannot be seen and held by its physical form but can be operated. The software functions as a bridge between the computer user and the hardware to process the data or commands desired by the user. Software required on the system the information built can be seen in table4-1.

Table 4-1 Software

\begin{tabular}{|c|c|c|c|}
\hline $\mathrm{NO}$ & Name & Spesification & Result \\
\hline 1 & $\begin{array}{l}\text { Operating } \\
\text { Sistem }\end{array}$ & $\begin{array}{c}\text { - Windows } \\
10 \\
\text { - Domain \& } \\
\text { Hosting } \\
\text { - Camera } \\
\text { P360 }\end{array}$ & \\
\hline 2 & Data Base & $\begin{array}{l}\text { - XAMPP } \\
\text { (MySql) }\end{array}$ & \\
\hline 3 & $\begin{array}{l}\text { Programming } \\
\text { System }\end{array}$ & $\begin{array}{c}\text { - PHP Versi } \\
5.0 \\
\text { - HTML } \\
\text { versi } 5.0\end{array}$ & \\
\hline 4 & Protocol & HTTP/GET & \\
\hline
\end{tabular}

\section{b. Hardware}

Hardware are physical components that are part of a computer system. The hardware functions as an executor of program commands through software that is implanted on the computer. equipment has a connection with a computer system through software. Computer hardware is interrelated in carrying out its duties The hardware specifications required in the system being built can be seen in the table.
Table 4-2 Hardware

\begin{tabular}{|c|c|c|c|}
\hline No & Nama & Spesifikasi & Ket \\
\hline 1 & $\begin{array}{l}\text { Komputer } \\
\text { (PC) }\end{array}$ & $\begin{array}{ll}- & \text { Prosesor } \\
\text { Intel Amda } \\
\text { A8 } \\
\text { - } & \text { Ram 4 GB } \\
\text { - } & \text { Hardisk } \\
& 500 \mathrm{~GB}\end{array}$ & \\
\hline & Monitor & 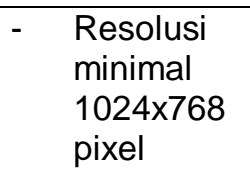 & \\
\hline 2 & keyboard & & \\
\hline 3 & Mouse & & \\
\hline
\end{tabular}

\section{c. System Implementation}

The use of the program can be implemented after all software components that support the application process of Indonesia Warship history information system in the ranks of the Republic of Indonesia web-based Fleet. If the usage process is done properly, the system is expected to run well.

\section{CONCLUSIONS AND RECOMENDATION}

\subsection{Conclusion}

From the various problems contained in the history of the Indonesia Warship it has been described and has been compiled by the author regarding the Indonesia Warship historical information system website in the ranks of the RI-based Indonesian fleet can be concluded:

a. The Indonesia Warship history website has been created so that Navy and community personnel can search for information about the history of Indonesia Warship PKR Sigma Indonesia Warship Raden Eddy Martadidinata 331 and Indonesia Warship I Guti Ngurah Rai 332 through the website. 
b. Hopefully this research will be very useful for all soldiers and the public.

c. With this website the range of information provided on this website will be wider.

d. The information system created can make it easier to process information data processing.

e. With this website it is expected to help the admin in controlling data information.

\subsection{Recomendation}

a. This website is still not perfect, there is still much to be developed for the better. as well as the addition of other content so that the website is more interactive so that it can advance further in the information field.

b. Creating a website is still very easy, especially in terms of appearance and security, both for the stage of developing a new system that is expected to be made as attractive as possible and continue to be developed with more complete additional information which of course will be more useful for website managers and users.

c. This web site design is expected to be more interactive so that the information the user wants is more useful.

d. With the final project report that has been made using the PHP program it is expected that the student concerned can take advantage of this program.

e. Regular data maintenance is required, especially related to the database.

f. This site still requires constant maintenance and analysis to find out deficiencies that the author might not have thought of while making the need for system development so that the site is better and able to keep up with time and technology.

\section{REFERENCES}

Connolly, Thomas and Begg, Carolyn. (2010). DataBase System: A Practical Approach to Design, Implementation, and Management, Fith Edition. Boston: Pearson Education.

Edhy, Sutanta. (2004). "Database system". Yogyakarta: Graha Science.

Kadir, A. (2003). "Introduction to information systems". Yogyakarta: Andi Offset.

Kroenke, DM. (2005). "Database processing: The basics, design and implementation". Jakarta: Erlangga.

Nugroho, Bunafit. (2007). "Complete guide to mastering SQL commands". Yogyakarta: PT TransMedia.

Paul Alexander (2004) "Formation of $3600^{\circ}$ Panorama Images 2.Bandung: Informatics.

Rozi, Zaenal A. and SmitDev Community. (2015). "Bootstrap Design Framework". Jakarta: Elex Media Komputindo.

Sutanta, Edhy. (2011). Database in Conceptual Review. Bujuki Andi. Yogyakarta.

Minarto, M., Majid, A., Ahmadi, A., \& Bukit, A. (2017). Rancang Bangun Aplikasi Sistem Pencatat Keluar Masuk Personel Di Penjagaan Sttal Surabaya Berbasis Rfid. International Journal Of ASRO - STTAL, 8, 1-16. Retrieved from http://asrojournalsttal.ac.id/index.php/ASRO/arti cle/view/223

Nanang, N., Bukit, A., \& Zulkifli, Z. (2017). Rancang Bangun Sistem Informasi Sintel Koarmatim Pada Aplikasi Security Clearance Berbasis Bluetooth Low Energy Dan 
Fingerprint. International Journal Of ASRO - STTAL, 8, 1-13. Retrieved from http://asrojournal-

sttal.ac.id/index.php/ASRO/arti cle/view/225

Jaya, I., Maryanto, E., Bukit, A., \& Zulkifli, M. (2018). Design And Development Of Early Heat Stroke Detection System In Military Cross Country Based On lot. International Journal of ASRO - STTAL, 9(2), 141-151. Retrieved from http://asrojournal-

sttal.ac.id/index.php/ASRO/arti $\underline{\text { cle/view/230 }}$

Sulistyono, E., Mahia, F., Bandono, A., \& Syahlan, Z. (2018). Design And Manufacture Of Indonesian Naval Warship Technical Condition Report And Inventory Information System. International Journal OF ASRO - STTAL, 9(2), 133140. Retrieved from http://asrojournal-

sttal.ac.id/index.php/ASRO/arti cle/view/229

Rozikin, C., Kurnianto, F., Ahmadi, A., \& Syaifi, M. (2018). Design Of Shooting Score Recording Information System Based On Image Processing. International Journal Of ASRO - STTAL, 9(1), 136-141. Retrieved from http://asrojournalsttal.ac.id/index.php/ASRO/arti cle/view/228 